\title{
Potential for cultural and eco-tourism in North East India: a community-based approach
}

\author{
P. Deb Burman ${ }^{1}$, L. Cajee ${ }^{2}$ \& D. D. Laloo ${ }^{3}$ \\ ${ }^{I}$ North Eastern Region Development Association \& INTACH, India \\ ${ }^{2}$ North Eastern Hill University, Shillong, India \\ ${ }^{3} \mathrm{MTDF}$, Meghalaya, India
}

\begin{abstract}
The North Eastern Region of India comprising eight states, including Sikkim, is a relatively unexplored and unique area, in terms of both geography and cultural diversity as it provides one with a glimpse of not just a 'mini India', but also of S.E Asia, all within a space of $265,000 \mathrm{sq}$. $\mathrm{km}$. The indigenous people belong to mainly the Mongoloid and Tibeto-Burman stock and have preserved their culture, language and way of life, even in the present century.

The rich flora, fauna, diverse topography and ethnic groups have of late, started attracting domestic as well as foreign tourists into the region and recently, community-based tourism has gained importance. While community-based tourism has been used to describe a variety of activities that seek to positively link conservation with economic development, many of the issues involved in the development of a community-based tourist area are not clearly defined. There are many concerns about managing negative impacts on local environments, while at the same time sufficiently involving local communities in the planning process to receive just benefits from tourism activities. This paper seeks to examine the potentiality of cultural and eco-tourism in the states of N.E India and the steps that need to be taken in order to make the above activity/industry into a sustainable one.
\end{abstract}

Keywords: sustainable eco-tourism, cultural tourism, biodiversity, North East India. 


\section{Introduction}

Tourism is one of the world's fastest growing industries. It is a major source of foreign exchange, domestic product, income and employment. Within this sector, a trend described variously as nature-based tourism (NBE) and ecotourism has emerged as a strong segment over the past few decades. Ecotourism is defined by the National Ecotourism Strategy as- "Nature-based tourism that involves education and interpretation of the natural environment and which is managed to be ecologically sustainable". It recognises that 'natural environment' includes cultural components and that 'ecologically sustainable' involves an appropriate return to the local community and long-term conservation of the resources.

From the above definition, it becomes apparent that eco-tourism, which in a larger context embraces rural, or village cultural tourism, nature-based tourism amongst others, may be seen as an important activity for sustaining, preserving and promoting indigenous communities and their lifestyle and heritage in fragile eco-systems, while promoting development and awareness amongst the community and region in particular, and at a national and world level, at large.

\section{Overview of the N.E. Region of India}

This paper seeks to examine the potential of eco and cultural tourism in the North Eastern states of India, the problems encountered and the measures to be taken to preserve, protect and promote the uniqueness of this lesser known territory and her people. A brief overview and history of the N.E region is required to help make our understanding of this area's tourism potential, better.

The ethnic, linguistic and cultural diversity of the region is as astounding as its lush hills, meandering rivers and verdant valleys. About $2 / 3 \mathrm{rds}$ of this region consist of hilly terrain while the rest is level or gently undulating land. Geographically the North East may be broadly divided into the Eastern Himalayan Range in the north (Arunachal Pradesh) merging with the Arakan Yoma Range (Myanmar), in the East, the Brahmaputra and Imphal valleys, Barak River Valley System and the Meghalaya Plateau. Ethnically, this region boasts of over 120 tribes and many more sub-tribes speaking 192 languages and dialects. Many races and cultures fuse and melt into the composite culture of the melting pot that is North East India.

Thus, this zone is diverse not just in terms of culture, geography, history and bio-diversity, but also unique for several 'Hot-spots',some of which have been granted heritage or endangered sites, especially in Arunachal Pradesh, Assam and Manipur. The British preferred to ignore the region, except for Assam, renowned for its tea, petroleum and the Rhino Sanctuary at Kaziranga, Shillong, the then capital, for it's cool climate and army cantontments. The inaccessible terrain, poor infra-structure and communication, the fear of the so-called 'savage hill people', wild animals, the relative isolation and the existence of tiny but severely independent 'chief-doms' and independent kingdoms of Hill Tipperah and Manipur, kept the Imperialists at bay, as they had little commercial interest. The situation remained almost the same after India's independence in 1947 and little was done to improve the lot of the indigenous people, who are referred to as 
'Scheduled Tribes', by the Constitution of India, and it is only lately that the Govt. of India has started to explore the possibility of tourism in this rich area, mainly because of the natural resources, cultural diversity and improved infrastructure, though much needs to be done, as the only means of communication is by air and a few roadways.

Ironically speaking, this isolation, under-development and lack of interest helped preserve and nurture the 'tribal way of life' and is now being marketed globally. However, this change, accompanied by rapid technology transfer and the lure for easy money, is paving the way for mass tourism, which is unsuitable for the region. Needless to say, this may lead to an over-exploitation of resources, both natural and human. Hence, a systematic assessment and a 'bottoms-up' approach is required, starting at the rural or community level, as the case may be.

\section{Potential areas for cultural and eco-tourism}

The dividing line between both cultural and natural heritage is small and tends to merge especially when taking the N.E states of India, into context, since the tribal encompasses nature in all aspects of his life, social, religious and economic. This proximity to nature is reflected especially in crafts, dance and customary laws and beliefs. Some of the states promoting eco and cultural tourism in the region are Meghalaya, Assam, Sikkim, Arunachal Pradesh, but recently Nagaland, Tripura and Mizoram have started exploring such possibilities too.

Some of the important areas for culture and eco-tourism that have immense potential in the region are elaborated below:

a) Tribal Culture - traditional festivals and performing arts

b) Eco-villages

c) Palaces and Temples

d) Buddhist Culture

e) Traditional Crafts

f) Museums and Village Cultural Centres - These include both Government and privately owned museums and may also extend to reserved areas which promote Tribal village centres.

\subsection{Tribal Cultural Tourism}

May be explored by way of traditional festivals, dances and folk art.

To experience life in these states one must stay in the villages or mingle with the tribals. A good way to understand tribal culture is to participate in their traditional festivals. These celebrations and fests occur normally during the spring, harvesting season and during religious ceremonies. Some notable fests and dances in the different states are-

\subsubsection{Nagaland}

The Angamis celebrate Sekrenyi, while the Konyaks important festival is the Aoling Monyu. The Aos celebrate Moatsu, the Tuluni by the Semas. Other 
festivals are Naknyulum, Metemneo, Amongmong, Tsokum, Tokhu Emong, Ngada and Monyu. Recently the Hornbill Festival at Kisama Naga Heritage Centre has become well known all over the world and is celebrated in early December, near Kohima.

\subsubsection{Mizoram}

The popular dances are- Cheraw, Chai Lam, Sarlamkai, Tlanglam, Chawng Laizawn and Khullam. Recently, a festival called the 'Anthurium Festival' was celebrated in spring this year and most of the dance and music were showcased, in order to promote their arts. Festivals associated with agriculture are Chapchar Kut, Mim Kut and Pawl Kut and are celebrated amidst lavish feasts.

\subsubsection{Meghalaya}

Has basically 3 major tribes though there are several clans amongst the Khasis, Jaintias and Garos. Major dances are the Shad Suk Mynsyiem, held in April, Nongkrem dance (November), the Wangala Dance (100 Drums fest), of the Garos and the Beh Deinkhlam (held in July), of the Jaintias. The Seng Khasi has helped promote and preserve the traditional art and dance forms as well as culture of the Khasis and these dances are performed with enthusiasm every year.

\subsubsection{Arunachal Pradesh}

Is the remotest and eastern-most part of India. Its isolation has been a blessing in disguise and the state is well preserved in every sense of the word-both in terms of nature and resources and culture. Arunachal is home to 26 major indigenous tribes and several more sub-tribes and so there are numerous dances. The significant ones are the Nyukom Yullow Festival (Nyishis), Mopin, Solung, Reh, Oriah, Dree, Moh Mol and several other Buddhist festivals/ fairs as well, such as Losar Festival, a 15 day festival which falls in January-February and its highlights are the Aji Lhamu Dance, Lion, Peacock and the Yak Dance, besides the Torgya Festival, Saka Dawa, Dukpa Tse-Shi and the Lhabab Duechin Festival.

\subsubsection{Sikkim}

The New Year or Losoong celebrations start with dazzling festivity and are followed by Guthor Chaam at the famous Rumtek Monastery later. Other important festivals are- Saga Dawa, Tse Chhu Chham (Mask Dance), Pang Lhabsol which is unique to Sikkim and the Kagye Dance. All these dances are basically Buddhist in character.

\subsubsection{Tripura}

There are about 19 tribes in the state and each one has a unique dance form and like with the other N. E states, are celebrated during spring and the harvesting season. In recent years some dances have become internationally known such as the Reang dance or_Hozagiri. Other dances are Jhum, Maimita, Masak Sumani and Lebang Boomani of the Tripuris, Bizhu by the Chakmas while the Meiteis celebrate spring with the Basant Raas and Pung Cholom. In North Tripura at Jampui where Mizos predominate, their local dances are performed. Most tribal 
festivals are accompanied by music and dance during Garia Puja and Kharchi and are performed by mostly the Tripuris, Kolois and Jamatias.

\subsubsection{Manipur}

Manipur has managed to gain international fame by preserving her traditional dance forms. Important amongst these are Lai Haraoba (Spring Festival), Yaosang which is Manipur's biggest festival, Ta Khousural and Thang Yannaba (Martial dances), Raas Leela, Khamba Thoibi as well as traditional Polo (Sagol Kangjei), Yubi- Lakpi (traditional rugby and wrestling hockey (Mukna Kangjei).

\subsubsection{Assam and Mikir Hills}

Bohag Bihu, is celebrated all over Assam and is by far the most popular of agriculture based festivals and ushers in the New Year. Of late, the Rongali Utsav (Spring Festival) has gained more importance and is celebrated at Srimanta Sankardeva Kalakshetra, a sprawling cultural centre, housing a museum, library and art galleries, portraying the rich cultural traditions of the land.

Assam now hosts other festivals such as- Dehing-Patkai Festival (at Lekhapani) and offers circuits such as a) Tea, Wildlife and Adventure; b) Tea and Golf and c) Tea and Tribal Village Circuit and visits to War Cemeteries and the historic Stilwell Road.

The Ambubachi Mela at Kamakhya temple, Tea festival at Jorhat and the Ras Mahotsav are other festivals. The tribals of Assam celebrate Baishagu (Bodo New Year), Rongker (Karbi), and the Ali-ai- Ligang (Mishmi). The Dimasas have an annual socio-religious festival called Rajini Gabra and Harni Gabra and is performed before the spring sowing season. Other spring fests are-Baikho (Rabha), Bohaggiyo Bishu (Deori) and are celebrated with the same spirit as Bohagi Bihu.

\subsection{Eco-villages}

Eco-tourism is a new concept in the North East of India and the indigenous people have lately started to take a keen interest in preserving their villages and sacred forests. Meghalaya, Nagaland, Arunachal Pradesh and Assam have come up with a few 'Tribal Villages', which showcase their culture, crafts, people, food and house types. Nagaland has an eco-complex called 'Kisama Village', Tuophema Tourist Village, besides others, and Meghalaya, which is renowned for her hills, waterfalls and for receiving the highest rainfall in the world, has villages in the southern plateau (near Cherrapunji), such as Mawlynnong, and Laitkynsew, which are unique for they have a natural wonder, such as the 'Living Root Bridges', a 'natural bridge' made of the buttress roots of wild rubber trees, which have been preserved by the village people for centuries. One of the concerns of the people is that the place should be given the status of World Natural Heritage Site and carbon dating done to estimate the age of the trees and bridges. Mawlynnong has also been accorded the status of being the "Cleanest Village' in South Asia, recently.

More research and impact assessment analysis needs to be done for the different states in the N.E. Region, such as in Arunachal Pradesh, Tripura, 
Manipur, etc, and the stake-holders defined clearly, so as to make this activity into a sustainable one. As of now, there has been no logical planning and the villagers and the local village 'Head-men' have taken the initiative. The Government needs to analyze the programme well in order to prevent misuse and over-exploitation of the natural and human resources, by estimating the carrying capacity of the fragile eco-system, documenting and assisting the local people by training them and respecting their traditional set-up, as commercialization will ruin the region at large.

\subsection{Palaces, temples and monuments}

Tripura, Assam Valley and Manipur have an interesting mix of both Aryan and non-Aryan people and the centuries old intermingling has resulted in cultural diversity and a richness of culture found in no other state in the East. Most of Palaces, temples and historic monuments are found in these States, as they were princely states before independence and were ruled by powerful native chiefs and princes in the historical past. Sikkim too was a kingdom and hence has much to offer by way of monuments. Let us briefly examine the important monuments and palaces in these states.

\subsubsection{Tripura}

An erstwhile tribal kingdom, Tripura was divided into independent Hill Tipperah and also extended up to the plains of present day Sylhet, parts of Cachar hills and as south as the tips of the Arakan. Hence, one finds several temples, monuments and Palaces in the most unlikely places of the state. Prominent among these are Ujjayanta Palace which was used as a Legislative Assembly, is an imposing, white building, set amidst Mughal gardens and fountains. It is ideally located in the capital city of Agartala, and was completed in 1901 by the then ruler Radha Kishore Manikya. It happens to be a major tourist site and near the Palace complex, one can also find the Jagannath and Govindji temples.

Other temples which are well known are-

Tripura Sundari Temple, situated at Udaipur, a sacred 'temple town,' is regarded as one of the 51 Pithas of Hindu Pilgrims. It was constructed in 1501 by Maharaja Dhanya Manikya. Not far from the temple, one finds the Bhuvaneshwari temple, which is said to have inspired Tagore, in the composition of one of his plays.

Neermahal- It is the only "Lake Palace" in East India. Built in 1930 by Maharaja Bir Bikram Manikya, it is situated in the middle of Rudrasagar lake and is situated about $53 \mathrm{~km}$ from Agartala and attracts many visitors from India and abroad.

Unakoti is an important archaelogical site (circa 7-9 century A.D), located in North Tripura, about $180 \mathrm{~km}$ from the capital. Several rock carvings and statues are found here on the hill slopes-both Buddhist and Hindu, in nature. Excavations have helped unearth more cut images and the Shiva and Ganesh heads are the largest Bas-relief sculpture in India. Unakoti is also a place of pilgrimage and fairs are held here annually. 
Besides Unakoti, Pilak has also emerged as a significant Buddhist site and has remains from the 8-9th centuries. Several terracotta plaques, statues and stone images of Avolokiteshwara including Narasimha have been discovered here. This place can serve as part of a Buddhist culture tourist route and centre, as visitors from Chittagong normally visit this site.

Deotamura has interesting panels of images carved on the hills facing the river Gomati.

Kamalasagar Kali Temple is situated in the Bangladesh border and was constructed in the 15 th century.

The temple of the Fourteen Gods or Chaudha Devta, located not far from Agartala, is also ancient and is unique as it houses the busts of 14 Tribal Gods, who have a similarity with Hindu Gods belonging to the early Aryan Period.

Tripura has many old ruins of palaces and temples and excavation work are still being undertaken. The state has great potential for culture tourism if promoted in a sustainable manner.

\subsubsection{Assam}

Assam was home to the Ahoms, who ruled for about 600 years from their capital Charaiadeo, near present day Sibsagar. As such, remains of old palaces, burial vaults similar to Egypt's pyramids are found here. Places worth visiting here are the Talatal Ghar, built by king Rudra Singha in 1699 AD and the Ahom Museum.

Besides palaces, Assam is better known for her temples, the most famous being the Kamakhya temple at Dispur. Other holy places located nearby are the Bashishta Ashram, Nabagraha temple, Ugratara Temple, Dirgeshwari and Ashvaklanta Temples.

Tezpur is located $174 \mathrm{~km}$ away and several sculptures are found here dating back to the 6th century. Other important towns are Hajo, which has the Hayagrib Madhab Temple, containing a relic of the Buddha and the Madan Kamdev archaelogical site, which has temples from the 10-12 centuries.

Majuli island is the world's largest, inhabited riverine island and is renowned for its important 'Satras" (Vaishav Monasteries) and is home to the Mishing tribe, who migrated from Arunachal Pradesh and have preserved their tribal identity and culture well.

\subsubsection{Manipur}

Manipur was another ancient kingdom and has some temples and palaces as well. The important ones are-

Langthabal an old palace, near the Myanmar border, Shaheed Minar, War Cemetery and the State Museum.

The state is an important temple town as well and most of the Meiteis are Vaishnavites. The Govindjee temple near the Royal Palace at Imphal is also famous as a pilgrim center.

Manipur is however, best known for her Performing Arts- both dances and Martial. 


\subsection{Buddhist Culture}

The states of Arunachal Pradesh and Sikkim are unique in their own way with respect to their native people and culture, but geographically they come under the Himalayan Range and share some similarities with regards to religion, namely Buddhism and Buddhist sites, near the Indo-Tibetan border. This can prove to be a potential area for Culture tourism, especially as an important Buddhist Pilgrim site and as we will discuss later, cooperating in a regional arrangement, lets one develop regional themes and resource pools and can prove very beneficial for tourism. Some important sites in these states are-

At Arunachal Pradesh in Tawang and adjoining areas; The Great Tawang Monastery is the second largest after the Potala in Tibet. Then there are the Urgelling, Taktsang, Rigyalling Monasteries and a very old nunnery, namely the Brahma Dungchung Ani Gompa, commissioned in 1595. Besides these, one may mention the following-Gyanganga Ani Gompa, Singsur Ani Gompa and the 12th century Gorsam Chorten at Zemithang, the largest in the area.

Sikkim: Institute of Tibetology is a premier institute renowned the world over and houses rare Buddhist books and Thankas, documents and original teachings of the Buddha. The Enchey Monastery, Do-drul Chorten (Stupa), Phodong, Rumtek, Pemayangtse, Sangacholing Monasteries are well known.

It must be noted that several festivals, dances and rituals connected with Mahayana and Tibetan Buddhism is practiced in these states, amidst great pomp and show.

Besides Buddhist Cultural sites, these states have ancient Hindu Pilgrim sites and temples as well, such as the Parshuram Kund, Vismaknagar, Malinithan in Arunachal and Ganesh Tok in Gangtok.

\subsection{Traditional crafts}

Traditional crafts of the North east needs to be included as a part of Culture Tourism. Most of the states are excellent with bamboo and cane work and baskets, mats, boxes, vases and a wide array of beautiful items are made, though not on such a large scale, as these are normally produced for local use.

Traditional textiles, such as the famed Muga silk of Assam, the fine cotton puans and lungis, bed-covers, woollen shawls and scarves are also produced by all the states, especially Nagaland, Manipur and Mizoram. Traditional weaving plays an extremely important part in the region's economy and culture and must be promoted at all costs. Tours to handicraft centres and traditional Villages where weaving is done can be an added attraction.

\subsection{Museums and Village Cultural Centres}

They play an important part in preserving and promoting Tribal Culture but unfortunately not much has been done. Most museums are Government owned thought there are some private ones as well.

A good example of a Tribal Museum is one located at Shillong, namely the Don Bosco (DBCIC) Museum, which is the largest of its kind in Asia. It 
provides the visitor with a bird's eye view of the North east and its indigenous people and has a good library and media centre as well.

Guwahati has a large Cultural Museum as well, the Srimanta Sankardeva Kalakshetra Cultural center and hosts festivals there as well.

\section{Problems}

Though there is much to be seen and experienced in the region, there are still a lot of obstacles that have prevented tourism from developing in a sustained manner. These are:

i) Poor Communication systems, especially transport as the region is landlocked and is connected to the rest of the country by only a $22 \mathrm{kms}$ narrow 'chickenneck', and at times of natural crisis such as landslides, floods, etc, the region gets completely cut-off from the sub-continent.

ii) Rigid laws and restrictions for travelers into the region are another impediment and the Govt. of India has certain permits such as the R.A.P (Restricted Area Permit), I.L.P (Inner Line Permit) and both Indian nationals and foreigners have to abide by them to gain entry into some of the states in the N.E of India.

iii) Infra-structure and hotels are few in number and they need to be improved and village homes and country-stays should be encouraged. The stakeholders and owners should be trained in hospitality, yet preserve their traditional homes and food-habits.

iv) Government Policy and general stability and security are a very important factor and stability in all the states and are necessary for any long-term sustainable eco-cultural-tourism plan in the region. Insurgency is a deterrent and though the situation is not too bad, tourists fear going to the N.E. region as curfews called by the insurgents are common.

v) Lack of proper advertising, marketing, networking and publishing of materials relating to the N.E. region of India is yet another problem. Very few travelers, even in India, have little idea about the region and consider some of the states to be alien and dangerous.

vi) The lack of documentation and protection of heritage sites and monuments in the region.

\section{SWOT analysis}

To outline strategic planning and a workable framework for preserving and sustaining eco-cultural tourism in the region, a SWOT analysis is important and some of the points are given herewith:

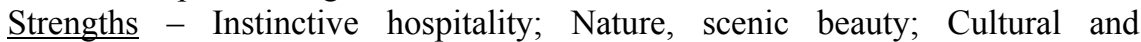
environmental heritage; Alternative healing through indigenous, medicinal plants and traditional massages; moderate climate.

Weakness - No awareness of tourism being a sustainable livelihood; No human resource development; Low-literacy level; Poor connectivity; Insurgency in a few areas. 
Opportunities - The Government of India's special emphasis on North East Tourism; Special Central assistance schemes; Investment by far-sighted entrepreneurs and local bodies like the MTDF members (Meghalaya);

Threats - Tourism growth to adversely affect the cultural and social structure of destination societies; Ecological imbalances in environmentally fragile locations; Militancy in some regions; Superstition and backwardness amongst some tribes.

\section{Concluding remarks}

Before formulating a plan or proposal for eco and cultural tourism in any locale or region, it would be desirable to observe certain guidelines and steps, such as those laid by the Convention on Biological Diversity, signed at the Rio Earth Summit, 1992, for promoting sustainable development and the WTO Committee on Sustainable Development of Tourism (2004). These are briefly summarised here-

a) Identification of potential areas; b) identification of Stake holders and developing effective working relationships; c) To identify, locate and determine the existing information, potential areas, heritage assets in the region based on documents, research \& local knowledge; d) Identifying issues, relating to the community, infra-structure and economic or marketing of resources; e) Security and political factors; f) heritage conservation analysis; g) SWOT Analysis to determine the marketability and strengths and weaknesses of the area; $h$ ) priority and cost analysis, are some of the important factors that need to be taken into account. The setting up of goals and objectives are very important for planning, though one needs to be flexible, for achieving these ends.

Developing cultural and eco-tourism is an incremental process, and one must keep in mind that developing a strong programme will require an investment and a commitment - an investment of financial resources and a commitment of human resources including strong leadership. In conclusion, it may be said that the N.E. states of India have immense potential for both eco and cultural tourism and this activity may be said to be one of the safest means of sustaining local and indigenous livelihoods, traditions and their cultural heritage.

\section{References}

[1] Jamieson, Walter and Alix Noble, Manual for Sustainable Tourism Destination Management, CUC-UEM Project, AIT, 2000.

[2] Deb Burman Pragya, Potential of Culture Tourism in North East India, Indian National Trust for Art and Cultural Heritage, Kohima, 2006. 